\title{
PENGARUH MODEL PEMBELAJARAN GUIDED DISCOVERY TERHADAP KETERAMPILAN PROSES SAINS SISWA SMP NEGERI 3 SUKASADA
}

\author{
Lya Fransiska, I Wayan Subagia, Putri Sarini \\ Program Studi S1 Pendidikan IPA \\ Universitas Pendidikan Ganesha \\ Singaraja, Indonesia \\ e-mail: \{lya.fransiska, wayan.subagia, putri.sarini\}@undiksha.ac.id
}

\begin{abstract}
Abstrak
Penelitian ini bertujuan untuk mendeskripsikan dan menjelaskan pengaruh model pembelajaran guided discovery terhadap keterampilan proses sains siswa. Populasi penelitian ini adalah seluruh siswa kelas VII SMP Negeri 3 Sukasada tahun ajaran 2017/2018. Pengambilan sampel dilakukan dengan teknik simple random sampling. Desain penelitian yang digunakan dalam penelitian ini adalah non-equivalent pretest-posttest control group desaign. Data keterampilan proses sains siswa dikumpulkan dengan menggunakan tes keterampilan proses sains. Data dianalisis dengan menggunakan uji ANCOVA satu jalur yang dilakukan terhadap angka signifikansi nilai statistik $F$ varian dengan taraf signifikansi 0,05 . Hasil penelitian menunjukkan bahwa angka signifikansi nilai statistik $F$ varian adalah 0,000 yang berarti bahwa $\mathrm{H}_{0}$ ditolak. Hal ini menunjukkan bahwa terdapat perbedaan keterampilan proses sains antara siswa yang diberi pelajaran dengan menggunakan model pembelajaran guided discovery dan siswa yang diberi pelajaran dengan menggunakan model pembelajaran konvensional. Dengan demikian, penerapan pembelajaran dengan model pembelajaran guided discovery memberikan pengaruh positif terhadap keterampilan proses sains siswa.
\end{abstract}

Kata kunci: keterampilan proses sains, model pembelajaran guided discovery, model pembelajaran konvensional

\begin{abstract}
This study aims to describe and explain the influence of guided discovery learning model to the students science process skills. The population of this study are all students grade 7 of SMPN 3 Sukasada academic year 2017/2018. Sampling is done by simple random sampling technique. The research design used in this study was non-equivalent pretest-posttest control group desaign. Data on students science process skills are collected by using students science skill test. The data were analyzed by using oneway ANCOVA test conducted on the statistical significance value of $F$ variance with significance level of 0,05 . The result showed that the significance of the statistical value of $F$ variant is 0,000 which means that $H_{0}$ is rejected. This indicates that there is a difference in the science process skill between students who are taught by using guided discovery learning model and students who are taught using conventional learning model. Thus, the application of learning by using guided discovery learning model positively influences students science process skills.
\end{abstract}

Keywords: science process skills, guided discovery learning model, conventional learning model

\section{PENDAHULUAN}

Pembangunan yang disertai dengan perkembangan IImu Pengetahuan dan Teknologi (Iptek) pada era globalisasi ini berkembang pesat. Hal ini perlu didukung oleh kinerja dunia pendidikan yang profesional dan memiliki mutu tinggi. Pembangunan di suatu negara tidak bisa terlepas dari bagaimana negara itu memperlakukan dan mengembangkan pendidikan. Dunia pendidikan yang bermutu diharapkan dapat mendukung lahirnya generasi muda penerus bangsa yang terampil, cerdas dan berwawasan luas sehingga mampu bersaing dengan negara lain pada era globalisasi. Karena pada hakikatnya, fungsi pendidikan seperti yang 
tertuang dalam Undang-Undang Nomor 20 Tahun 2003, yaitu untuk mengembangkan kemampuan serta meningkatkan mutu kehidupan dan martabat manusia.

Pembangunan Indonesia pada era globalisasi ini perlu diarahkan untuk meningkatkan Sumber Daya Manusia (SDM) yang berkualitas dan memiliki keterampilan kompetitif agar mampu bersaing dengan negara lain. Laju perkembangan Iptek dan proses globalisasi secara tidak langsung telah menuntut agar masyarakat di suatu negara terus mengejar kualitas dan keunggulan, menuntut masyarakat yang bercirikan kreatif, kritis, fleksibel, terbuka, inovatif, tangkas, kompetitif, peka terhadap masalah, menguasai informasi, mampu bekerja dalam "team work" lintas bidang, dan mampu beradaptasi terhadap perubahan (Sudargo \& Soesy, 2010). Salah satu cara untuk meningkatkan kualitas dan keterampilan Sumber Daya Manusia (SDM) yaitu dengan cara pembekalan kepada siswa sebagai generasi penerus bangsa melalui pembelajaran di bangku sekolah. Pembelajaran yang diperlukan bukanlah pembelajaran yang hanya mengutamakan hasil, namun juga harus meningkatkan proses yang dilakukan oleh siswa untuk mendapatkan suatu hasil. Dengan demikian, siswa dilatih untuk mengembangkan keterampilan yang ada melalui proses pembelajaran yang melibatkan siswa secara langsung sehingga siswa mengalami sendiri apa yang mereka pelajari. Keterampilan proses yang dimiliki siswa berpotensi membangun kompetensi dasar hidup melalui sikap ilmiah dan proses konstruksi pengetahuan secara bertahap.

Salah satu mata pelajaran yang turut berperan penting dalam mengembangkan keterampilan dan sikap ilmiah sejak dini bagi siswa adalah mata pelajaran IPA.

IPA atau sains pada hakikatnya terdiri dari tiga hal, yaitu produk, proses dan sikap. IPA sebagai produk meliputi sekumpulan pengetahuan yang terdiri dari fakta-fakta, konsep-konsep, dan prinsipprinsip. IPA sebagai proses, meliputi keterampilan-keterampilan dan sikap-sikap yang dimiliki oleh para ilmuwan untuk mencapai produk sains yang disebut sebagai keterampilan proses sains (Suastra, 2009).

Ozturk et al. (2010) menyatakan bahwa keterampilan proses sains merupakan keterampilan yang membuat belajar Iptek dengan mudah, mengembangkan rasa ingin tahu siswa dan membuat mereka aktif, memperkenalkan suasana laboratorium dengan mendorong siswa untuk membuat penelitian melalui praktikum dan memfasilitasi untuk menyampaikan belajar dari pelajaran Iptek ke kehidupan nyata. Sementara itu Padila (dalam Duran \& Özdemir, 2010) mendefinisikan keterampilan proses sebagai keterampilan yang ditransfer berlaku untuk banyak ilmu dan yang mencerminkan perilaku para ilmuwan. Keterampilan proses sains memiliki dasardasar, yaitu: (1) observasi, (2) mengukur, (3) menduga/menyimpulkan, mengklasifikasi, (5) memprediksi, dan (6) menyampaikan (Lancour, 2009).

Dalam pembelajaran IPA, antara IPA sebagai produk dan IPA sebagai proses harus mendapatkan penekanan yang seimbang. Selama ini, tampaknya pengajaran IPA di sekolah lebih menekankan IPA sebagai produk dibandingkan IPA sebagai proses. Bahkan, seringkali proses sains dalam pembelajaran IPA di sekolah diabaikan. Keterampilan proses sangat perlu dikembangkan dalam pembelajaran agar siswa memahami hakikat sains sebagai proses, produk dan sikap ilmiah (Suastra, 2009).

Hal tersebut diperkuat oleh penelitian yang dilakukan oleh Ardiansyah (2014) yang menunjukkan bahwa keterampilan proses sains siswa masih kurang ditangani oleh guru di sekolah. Harapan tumbuhnya sifat kreatif dan antisipatif para guru dalam praktek pembelajaran untuk memaksimalkan peranan siswa yang masih belum optimal sehingga menjadi penyebab kurangnya kualitas dan kuantitas keterampilan proses sains siswa. Hal ini disebabkan oleh beberapa kendala, yaitu (1) siswa tidak terbiasa melaksanakan kegiatan praktikum, (2) sistem pembelajaran yang hanya bersifat transfer ilmu saja tanpa mengkonstruk sendiri 
pengetahuannya, dan (3) kurangnya penggunaan LKS (Lembar Kerja Siswa).

Hal yang senada juga diungkapkan oleh Kuswanto, Astalini dan Kurniawan (2017) yang menyatakan bahwa keterampilan proses yang dimiliki oleh mahasiswa dikategorikan tidak baik karena kurangnya pengamalan praktikum sewaktu SMA, waktu yang digunakan dalam melaksanakan praktikum singkat dan sarana serta prasarana pendukung kegiatan praktikum belum sepenuhnya mampu mendukung peningkatan keterampilan proses sains yang dimiliki oleh mahasiswa.

Pembelajaran IPA di sekolah hanya menekankan pada aspek produk tanpa mengembangkan aspek prosesnya, seperti menghafal konsep-konsep, prinsip-prinsip atau rumus, tidak memberikan kesempatan kepada siswa mengeksploitasi sendiri dalam pembelajaran, serta tidak dapat menumbuhkan sikap ilmiah siswa. Padahal, salah satu tuntutan yang diminta oleh kurikulum pada pembelajaran IPA di SMP selain memahami konsep-konsep sains siswa juga dituntut mampu menggunakan metode ilmiah untuk memecahkan masalah yang dihadapi. Dari tuntutan tersebut, guru diminta untuk dapat mencapai produk dan proses sains secara bersamaan dalam pelaksanaan kegiatan pembelajaran IPA di sekolah. Ini berarti bahwa selain mengembangkan fakta-fakta, konsepkonsep, dan prinsip-prinsip IPA, guru juga harus mengembangkan keterampilan proses sains siswa sebagai salah satu aspek yang terdapat pada hasil belajar (Warnata, 2009).

Pembelajaran konvensional yang selama ini diterapkan oleh guru di sekolah bisa dikatakan sebagai proses dalam belajar menghafal karena kegiatan pembelajaran ini menekankan pada penguasaan pengetahuan atau fakta-fakta atau konsep-konsep tanpa memberi makna terhadap pengetahuan atau fakta atau konsep tersebut. Brooks dan Brooks (dalam Juliantara, 2009) menyampaikan bahwa penyelenggaraan pembelajaran dengan menggunakan model pembelajaran konvensional lebih menekankan kepada tujuan pembelajaran berupa penambahan pengetahuan, sehingga belajar dilihat sebagai proses "meniru" dan siswa dituntut untuk dapat mengungkapkan kembali pengetahuan yang sudah dipelajari melalui kuis atau tes. Meskipun dalam pembelajaran konvensional digunakan metode selain ceramah yaitu metode diskusi dan didukung dengan penggunaan media yang dapat meningkatkan keterampilan berkomunikasi dan observasi, tetapi penekanannya tetap pada proses penerimaan pengetahuan (materi pelajaran), bukan pada proses pencarian dan konstruksi pengetahuan sehingga keterampilan proses sains tidak akan tercapai. Siswa juga sering menganggap pelajaran IPA adalah pelajaran yang rumit karena banyak terdapat konsep-konsep, hafalan-hafalan, rumus-rumus dan perhitungan-perhitungan yang sebagian besar terlepas dari pengalaman sainsnya setiap hari (Mardana, 2006). Hal tersebut bertolak belakang dengan pendapat Subagyo et al. (2009) yang menyatakan bahwa hakikat belajar sains tidak cukup sekedar mengingat dan memahami konsep yang ditemukan ilmuwan, melainkan adalah pembiasaan perilaku ilmuwan dalam menemukan konsep yang dilakukan melalui percobaan dan penelitian ilmiah. Dengan model pembelajaran seperti ini, dapat dilihat pembelajaran IPA di sekolah hanya menekankan pada hasil belajar saja tanpa mengikutsertakan proses dari pembelajaran tersebut sehingga mengakibatkan rendahnya keterampilan proses yang dimiliki oleh siswa.

Sampai saat ini, keterampilan proses sains siswa belum dikembangkan secara optimal dalam proses pembelajaran IPA karena proses pembelajaran belum mampu memfasilitasi siswa untuk belajar menggunakan metode ilmiah. Oleh karena itu, perlu diupayakan perencanaan dan pelaksanaan pembelajaran yang memberikan kesempatan kepada siswa untuk beraktivitas seperti ilmuwan agar mampu mengembangkan dan meningkatkan keterampilan proses sains. Guna mengembangkan kemampuan keterampilan proses sains siswa, perlu adanya model pembelajaran inovatif yang mampu mengarahkan siswa ke dalam 
penyelesaian masalah-masalah IPA dengan melibatkan kemampuan berpikir serta keterampilan proses siswa, model pembelajaran inovatif yang dimaksudkan juga tidak terlepas dari paham konstruktivistik dalam pembelajaran. Salah satu model pembelajaran inovatif yang dapat digunakan untuk mengembangkan keterampilan proses sains siswa adalah model pembelajaran guided discovery.

Model discovery learning atau model pembelajaran berbasis penemuan adalah model pembelajaran yang menjadikan siswa dapat menemukan sendiri konsepkonsep dan teori-teori pengetahuan dengan cara melakukan pengamatan, menggolongkan, membuat dan sebagainya untuk menemukan konsep atau teori tersebut (Sukardi, 2015).

Moedjiono dan Dimyati (1992) mengemukakan tujuan dari digunakannya model pembelajaran guided discovery dalam kegiatan belajar mengajar yaitu (1) meningkatkan keterlibatan siswa secara aktif dalam memperoleh dan memproses perolehan belajar, (2) mengarahkan para siswa sebagai pelajar seumur hidup, (3) mengurangi ketergantungan kepada guru sebagai satu-satunya sumber informasi yang diperlukan oleh para siswa dan (4) melatih para siswa mengeksplorasi dan memanfaatkan lingkungannya sebagai sumber informasi yang tidak akan pernah tuntas digali.

Dalam upaya mengembangkan keterampilan proses sains siswa, digunakan model pembelajaran yang mampu menggerakkan siswa untuk menumbuhkan keterampilan proses sains yang meliputi kemampuan mengamati, menafsirkan, meramalkan, menggunakan alat dan bahan, menerapkan konsep, merencanakan kegiatan, berkomunikasi, dan bertanya. Oleh karena itu, penulis mengangkat penelitian dengan judul "Pengaruh Model Pembelajaran Guided Discovery terhadap Keterampilan Proses Sains Siswa SMP Negeri 3 Sukasada".

Berdasarkan latar belakang masalah yang telah dipaparkan, maka pembatasan masalah dalam penelitian ini yaitu pada permasalahan penggunaan model pembelajaran konvensional yang meskipun telah dilengkapi dengan penggunaan media yang dapat meningkatkan keterampilan proses sains, tetapi penekanannya hanya pada aspek berkomunikasi, observasi dan proses penerimaan pengetahuan, bukan pada proses pencarian dan konstruksi pengetahuan atau hanya menekankan pada aspek produk tanpa melihat aspek prosesnya karena dalam pembelajaran IPA aspek produk dan aspek proses memiliki peranan yang sama penting dan tidak dapat dipisahkan. Permasalahan ini diharapkan dapat diselesaikan dengan melakukan penelitian eksperimen yang membandingkan keterampilan proses sains antara siswa yang diberi pelajaran dengan menggunakan model pembelajaran guided discovery dan siswa yang diberi pelajaran dengan menggunakan model pembelajaran konvensional.

\section{METODE PENELITIAN}

Penelitian ini merupakan penelitian eksperimen semu (quasi experiment) dengan menggunakan dua kelompok yang diberi perlakuan yang berbeda. Kelompok eksperimen diberi perlakuan dengan menggunakan model pembelajaran guided discovery dan kelompok kontrol dengan menggunakan model pembelajaran konvensional.

Rancangan penelitian yang digunakan dalam penelitian ini yaitu non-equivalent pretest-posttest control group design. Populasi dalam penelitian ini adalah seluruh siswa kelas VII SMP Negeri 3 Sukasada tahun ajaran 2017/2018 yang berjumlah 150 siswa. Pengambilan sampel dilakukan pada kelompok (random class/group). Proses randomisasi yang dilakukan untuk mendapatkan sampel penelitian yaitu dengan menggunakan teknik simple random sampling. Sampel yang dipilih dalam penelitian ini untuk kelompok eksperimen yaitu siswa kelas VII A dan untuk kelompok kontrol yaitu siswa kelas VII B.

Penelitian ini menggunakan dua metode pengumpulan data yakni tes dan dokumentasi. Instrumen yang digunakan untuk memperoleh data keterampilan proses sains siswa dalam penelitian ini 
yaitu instrumen yang berupa tes uraian, RPP, dan LKS.

Metode dan teknik analisis data yang digunakan dalam penelitian ini adalah dengan menggunakan statistik deskriptif dan statistik inferensial. Analisis statistik deskriptif digunakan untuk menganalisis skor rata-rata dan standar deviasi keterampilan proses sains siswa sebelum diberi perlakuan (pretest) dan keterampilan proses sains siswa setelah diberi perlakuan (posttest) untuk masing-masing model pembelajaran. Analisis statistik inferensial digunakan untuk menguji hipotesis yang diajukan dalam penelitian ini dengan menggunakan analisis kovariat (ANCOVA) satu jalur yang melibatkan satu variabel bebas dan satu variabel terikat (Arikunto, 2006). ANCOVA digunakan karena melibatkan variabel kovariat, yaitu pengetahuan awal siswa yang diukur dengan pretest.
Sebelum dilakukan uji hipotesis penelitian, data yang akan diolah dengan teknik ANCOVA harus memenuhi asumsi prasyarat analisis yang meliputi uji normalitas dengan menggunakan statistik Kolmogorov Test dan Shapiro-Wilks Test, uji homogenitas dengan menggunakan Levene's Test Equality of Error Variance dan uji linearitas dengan menggunakan Test of Linearity. Pengujian asumsi prasyarat dilakukan dengan menggunakan bantuan SPSS 16.0 for Windows.

\section{HASIL DAN PEMBAHASAN}

Nilai rata-rata $(M)$ dan standar deviasi (SD) keterampilan proses sains siswa pada kelompok eksperimen dan kontrol sebelum diberi perlakuan (pretest) dan sesudah diberi perlakuan (posttest) disajikan pada Tabel 1.

Tabel 1. Nilai Rata-Rata Pretest dan Posttest Keterampilan Proses Sains Siswa

\begin{tabular}{lcccccc}
\hline \multirow{2}{*}{ Kelompok } & \multicolumn{4}{c}{ Pretest } & \multicolumn{2}{c}{ Posttest } \\
\cline { 2 - 7 } & M & SD & Kualifikasi PAP & M & SD & Kualifikasi PAP \\
\hline Eksperimen & 44,72 & 5,854 & Rendah & 78,31 & 6,646 & Tinggi \\
\hline Kontrol & 31,69 & 8,629 & Sangat rendah & 56,20 & 6,334 & Cukup \\
\hline
\end{tabular}

Pada Tabel 1. terlihat pada pretest, kelompok eksperimen memperoleh nilai rata-rata 44,72 dengan kualifikasi rendah dan kelompok kontrol memperoleh nilai rata-rata 31,69 dengan kualifikasi sangat rendah. Pada posttest kelompok eksperimen maupun kelompok kontrol mengalami peningkatan nilai rata-rata. Kelompok eksperimen memperoleh nilai rata-rata 78,31 dengan kualifikasi tinggi dan mengalami peningkatan sebesar 33,59. Pada kelompok kontrol memperoleh nilai rata-rata 56,20 dengan kualifikasi cukup dan mengalami peningkatan nilai rata-rata 24,51 .
Berdasarkan selisih peningkatan nilai rata-rata pretest dan posttest dapat disimpulkan bahwa peningkatan nilai ratarata keterampilan proses sains pada kelompok eksperimen relatif lebih tinggi daripada kelompok kontrol.

Penelitian ini juga menganalisis sebaran nilai rata-rata masing-masing siswa sebelum (pretest) dan sesudah perlakuan (posttest) pada kelompok eksperimen dan kontrol berdasarkan penilaian acuan patokan (PAP). Distribusi sebaran nilai ratarata tes keterampilan proses sains siswa sebelum dan sesudah diberi perlakuan disajikan pada Tabel 2.

Tabel 2. Distribusi Sebaran Nilai Rata-Rata Pretest Keterampilan Proses Sains Siswa

\begin{tabular}{cccccc}
\hline \multirow{2}{*}{$\begin{array}{c}\text { Interval } \\
\text { Nilai }\end{array}$} & \multirow{2}{*}{ Kualifikasi } & \multicolumn{2}{c}{$\begin{array}{c}\text { Sebaran Nilai Rata-Rata } \\
\text { Pretest }\end{array}$} & \multicolumn{2}{c}{$\begin{array}{c}\text { Sebaran Nilai Rata-Rata } \\
\text { Posttest }\end{array}$} \\
\cline { 3 - 7 } & & Eksperimen & Kontrol & Eksperimen & Kontrol \\
\hline $85-100$ & Sangat tinggi & - & - & 6 & - \\
\hline $70-84$ & Tinggi & - & - & 19 & - \\
\hline
\end{tabular}




\begin{tabular}{cccccc}
\hline $55-69$ & Cukup & - & - & 5 & 17 \\
\hline $40-54$ & Rendah & 22 & 6 & - & 13 \\
\hline $0-39$ & Sangat rendah & 8 & 24 & - & - \\
\hline
\end{tabular}

Berdasarkan Tabel 2. sebaran nilai ratarata keterampilan proses sains siswa pada masing-masing kelompok kelas eksperimen dan kontrol sebelum diberi perlakuan (pretest) berada pada kualifikasi rendah dan sangat rendah. Pada saat setelah diberi perlakuan (posttest) kelompok eksperimen maupun kelompok kontrol mengalami peningkatan. Pada kelas eksperimen berada pada kualifikasi cukup, tinggi, dan sangat tinggi. Pada kelompok kontrol berada pada kualifikasi cukup dan rendah
Selain data keterampilan proses sains yang telah dipaparkan, dalam penelitian ini juga dianalisis skor yang diperoleh siswa sebelum (pretest) dan sesudah perlakuan (posttest) untuk setiap indikator keterampilan proses sains yang terdiri dari merencanakan kegiatan, bertanya, mengamati, menafsirkan dan menerapkan konsep. Skor dari setiap indikator keterampilan proses sains yang diperoleh dari hasil pretest dan posttest untuk kelompok eksperimen dan kontrol disajikan pada Tabel 4 dan 5 .

Tabel 4. Skor Awal Setiap Indikator Keterampilan Proses Sains Siswa

\begin{tabular}{clcccc}
\hline No & $\begin{array}{c}\text { Indikator Keterampilan } \\
\text { Proses Sains }\end{array}$ & $\begin{array}{c}\text { Eksperimen } \\
(\%)\end{array}$ & Kriteria & $\begin{array}{c}\text { Kontrol } \\
(\%)\end{array}$ & Kriteria \\
\hline 1 & Merencanakan kegiatan & 44 & Rendah & 35 & Sangat rendah \\
\hline 2 & Bertanya & 3 & Sangat rendah & 20 & Sangat rendah \\
\hline 3 & Mengamati & 55 & Cukup & 35 & Sangat rendah \\
\hline 4 & Menafsirkan & 43 & Rendah & 20 & Sangat rendah \\
\hline 5 & Menerapkan konsep & 28 & Sangat rendah & 26 & Sangat rendah \\
\hline
\end{tabular}

Berdasarkan Tabel 4. menurut Penilaian Acuan Patokan (PAP) dapat diketahui bahwa kelompok eksperimen memperoleh kriteria cukup pada indikator mengamati, kriteria rendah pada indikator menafsirkan, dan merencanakan kegiatan, serta kriteria sangat rendah pada indikator bertanya dan menerapkan konsep. Pada kelompok kontrol indikator merencanakan kegiatan, bertanya, mengamati, menafsirkan dan menerapkan konsep menurut Penilaian
Acuan Patokan (PAP) memperoleh kriteria sangat rendah.

Berdasarkan presentase skor yang diperoleh pada indikator merencanakan kegiatan, mengamati, menafsirkan dan menerapkan konsep, kelompok eksperimen memperoleh skor lebih tinggi daripada kelompok kontrol. Pada indikator bertanya kelompok eksperimen memperoleh presentase skor lebih rendah daripada kelompok kontrol.

Tabel 5. Skor Akhir Setiap Indikator Keterampilan Proses Sains Siswa

\begin{tabular}{clcccc}
\hline No & $\begin{array}{c}\text { Indikator Keterampilan } \\
\text { Proses Sains }\end{array}$ & $\begin{array}{c}\text { Eksperimen } \\
(\%)\end{array}$ & Kriteria & $\begin{array}{c}\text { Kontrol } \\
(\%)\end{array}$ & Kriteria \\
\hline 1 & Merencanakan kegiatan & 85 & Sangat tinggi & 50 & Rendah \\
\hline 2 & Bertanya & 78 & Tinggi & 45 & Rendah \\
\hline 3 & Mengamati & 70 & Tinggi & 57 & Cukup \\
\hline 4 & Menafsirkan & 81 & Tinggi & 76 & Tinggi \\
\hline 5 & Menerapkan konsep & 75 & Tinggi & 58 & Cukup \\
\hline
\end{tabular}

Pada Tabel 5. menurut Penilaian Acuan Patokan (PAP) dapat diketahui bahwa kelompok eksperimen memperoleh kriteria sangat tinggi pada indikator merencanakan kegiatan dan kriteria tinggi pada indikator bertanya, mengamati, menafsirkan dan 
menerapkan konsep. Pada kelompok kontrol indikator merencanakan kegiatan dan bertanya memperoleh kriteria rendah, indikator mengamati dan menerapkan konsep memperoleh kriteria cukup, dan indikator menafsirkan memperoleh kriteria tinggi.

Berdasarkan presentase skor yang diperoleh kelompok eksperimen memperoleh presentase skor lebih tinggi daripada kelompok kontrol pada indikator merencanakan kegiatan, bertanya, mengamati, menafsirkan dan menerapkan konsep.

\section{Uji Prasyarat Analisis Data Uji Normalitas}

Hasil uji normalitas dengan menggunakan statistik KolmogorovSmirnov dan Shapiro-Wilk menunjukkan bahwa nilai signifikansi pada kedua uji statistik pada kelompok eksperimen dan kontrol lebih besar daripada 0,05 yang artinya bahwa data telah berdistribusi normal.

\section{Uji Homogenitas}

Hasil uji homogenitas dengan menggunakan Levene's Test of Equality of Error Variance menunjukkan bahwa nilai statistik Levene's memiliki signifikansi lebih dari 0,05 yang artinya varian antar kelompok model pembelajaran adalah homogen.

\section{Uji Linearitas}

Hasil uji linearitas antar kelompok diuji dengan menggunakan Test of Linearity menunjukkan bahwa nilai statitik yang diperoleh berada pada taraf signifikansi lebih besar daripada 0,05 yang artinya data yang diuji bersifat linier.

\section{Uji Homogenitas Kemiringan Garis Regresi (Uji Interaksi)}

Hasil uji interaksi menunjukkan bahwa nilai signifikansi yang diperoleh lebih besar dari 0,05 yang artinya tidak terdapat interaksi antara skor awal keterampilan proses sains yang diperoleh siswa (pretest) dengan skor akhir keterampilan proses sains (posttest) yang diperoleh siswa.

\section{Uji Hipotesis}

Hipotesis yang akan diuji secara statistik adalah $\mathrm{H}_{0}$ yaitu tidak terdapat perbedaan keterampilan proses sains antara siswa yang diberi perlakuan dengan menggunakan model pembelajaran guided discovery dan siswa yang diberi perlakuan dengan menggunakan model pembelajaran konvensional. Apabila nilai signifikansi statistik $F$ varian lebih besar dari 0,05 maka $\mathrm{H}_{0}$ diterima dan $\mathrm{H}_{0}$ ditolak apabila nilai signifikansi statistik $F$ varian kurang dari 0,05. Ringkasan hasil uji ANCOVA satu jalur tersaji pada tabel 6 .

Tabel 6. Ringkasan Hasil Uji ANCOVA Satu Jalur

\begin{tabular}{|l|r|r|r|c|c|}
\hline Source & $\begin{array}{r}\text { Type III Sum of } \\
\text { Squares }\end{array}$ & df & Mean Square & F & Sig. \\
\hline Corrected Model & 1211,126 & 1 & 1211,126 & 61,823 & 0,000 \\
Intercept & 864,175 & 1 & 864,175 & 44,112 & 0,000 \\
pretest & 1211,126 & 1 & 1211,126 & 61,823 & 0,000 \\
Error & 1136,241 & 58 & 19,590 & & \\
Total & 67515,880 & 60 & & & \\
Corrected Total & 2347,367 & 59 & & & \\
\hline
\end{tabular}

Berdasarkan ringkasan hasil uji ANCOVA satu jalur yang tersaji pada tabel 6 dapat diinterpretasikan bahwa pengaruh model pembelajaran terhadap keterampilan proses sains siswa memiliki nilai statistik $F$ sebesar 61,823 dengan angka signifikansi kurang dari 0,05 yang berarti $\mathrm{H}_{0}$ ditolak. Dengan demikian keterampilan proses sains siswa secara signifikan dipengaruhi oleh model pembelajaran yang digunakan dalam kegiatan pembelajaran. 
Model pembelajaran guided discovery yang digunakan pada proses pembelajaran di kelas eksperimen mampu untuk meningkatkan keterampilan proses sains yang dimiliki siswa dikarenakan dalam proses pembelajarannya siswa diberi kesempatan untuk belajar secara mandiri dan lebih aktif untuk menemukan konsep/fakta IPA sehingga berdampak pada meningkatnya keterampilan proses sains siswa. Ini sejalan dengan penelitian yang dilakukan oleh Handayani et al. (2017) yang menunjukkan bahwa model pembelajaran guided discovery dapat meningkatkan keterampilan proses sains siswa dikarenakan dalam proses pembelajaran siswa dibimbing untuk menyelidiki dan menemukan sendiri fakta/konsep IPA, sehingga keterampilan proses sains dan pengetahuan yang mereka peroleh merupakan temuan sendiri.

Pada model pembelajaran guided discovery, langkah-langkah yang terdapat di dalamnya memungkinkan siswa untuk belajar lebih aktif dan dapat meningkatkan keterampilan proses sains yang dimilikinya. Terdapat delapan tahap pembelajaran dalam model pembelajaran ini, yaitu (1) observasi, (2) merumuskan masalah, (3) mengajukan hipotesis, (4) merencanakan pemecahan masalah melalui percobaan atau cara lain, (5) melaksanakan percobaan, (6) melaksanakan pengamatan dan pengumpulan data, (7) analisis data dan (8) menarik kesimpulan atas percobaan yang telah dilakukan.

Penerapan pembelajaran IPA dengan model pembelajaran guided discovery pada tahap observasi, siswa diarahkan untuk mengamati suatu objek yang berkaitan dengan materi pembelajaran dan menyelesaikan LKS yang diberikan, sehingga pada tahap ini membiasakan siswa untuk melatih keterampilan proses sains pada aspek mengamati. Selanjutnya, yaitu tahap merumuskan masalah, pada tahap ini siswa diarahkan untuk dapat merumuskan suatu permasalahan yang sesuai dengan tujuan dilakukannya kegiatan percobaan. Setelah siswa dapat merumuskan permasalahan yang sesuai dengan tujuan praktikum maka dilanjutkan dengan mengajukan hipotesis. Pada tahap mengajukan hipotesis, siswa diarahkan untuk dapat mengajukan hipotesis yang mereka miliki berdasarkan observasi yang telah dilakukan dan rumusan masalah yang telah dibuat. Pada tahap merumuskan masalah dan mengajukan hipotesis ini, setiap kelompok diminta untuk menyampaikan rumusan masalah dan hipotesis yang telah mereka buat, sehingga siswa terlatih untuk terbiasa mengkomunikasikan jawaban yang mereka miliki. Selama tahap ini berlangsung, siswa dituntut untuk membiasakan keterampilan proses sains mereka dalam aspek bertanya atau mengajukan rumusan masalah, menerapkan konsep dan meramalkan. Setelah mendiskusikan mengenai rumusan masalah dan hipotesis dalam LKS, siswa akan menuliskan rumusan masalah yang telah disepakati pada buku tugas. Selanjutnya, tahap merencanakan kegiatan, setelah rumusan masalah dan hipotesis didapatkan, siswa diarahkan untuk merencanakan dan menyiapkan alat dan bahan yang dapat digunakan untuk melaksanakan kegiatan praktikum yang disesuaikan dengan tujuan diadakannya kegiatan praktikum. Selain diarahkan untuk merencanakan dan menyiapkan alat dan bahan, pada tahap ini siswa juga diarahkan untuk menentukan variabel penelitian. Pada tahap ini siswa diituntut untuk membiasakan aspek keterampilan proses sains mereka pada aspek merencanakan kegiatan. Selanjutnya, pada tahap melaksanakan praktikum, pengamatan dan pengumpulan data, siswa diarahkan untuk melaksanakan serangkaian kegiatan praktikum dan pengamatan berdasarkan langkah-langkah kegiatan praktikum yang telah terdapat di LKS. Setelah praktikum dan pengamatan selesai dilakukan maka siswa diarahkan untuk melakukan pengumpulan data dengan mencatat hasil praktikum dan pengamatan pada buku tugas serta berdiskusi dengan teman kelompok mengenai hasil praktikum yang telah diperoleh. Selama tahap ini berlangsung, siswa dituntut untuk membiasakan keterampilan proses sains pada aspek menggunakan alat dan bahan, mengamati, menafsirkan dan berkomunikasi. Selanjutnya, yaitu tahap 
analisis data, siswa dengan dibantu oleh guru menganalisis hasil praktikum yang telah dilakukan untuk menemukan konsep, sehingga pada tahap ini siswa dapat terbiasa untuk menerapkan keterampilan proses sains pada aspek menafsirkan. Pada tahap terakhir yaitu menarik kesimpulan, siswa diminta untuk menarik kesimpulan terhadap kegiatan praktikum yang telah dilakukan kemudian menyampaikan konsep yang ditemukan. Selama tahap ini berlangsung, keterampilan proses sains yang diperoleh siswa adalah aspek menafsirkan dan berkomunikasi.

Model pembelajaran guided discovery merupakan rangkaian aktivitas pembelajaran yang didalamnya terdapat sejumlah kegiatan yang harus dilakukan siswa. Guided discovery tidak mengharapkan siswa hanya sekedar mendengarkan, mencatat, kemudian menghafalkan materi pembelajaran, akan tetapi melalui kegiatan penemuan (discovery) siswa akan terlibat secara aktif dalam kegiatan pembelajaran sehingga siswa dapat mengkonstruksi sendiri pengetahuan yang dimilikinya melalui suatu kegiatan penemuan dan proses ilmiah yang melibatkan kegiatan penyelidikan atau eksperimen sebagai bagian dari kinerja ilmiah (Lete, et al., 2016).

Model pembelajaran guided discovery menekankan pada pengalaman belajar aktif yang berpusat pada siswa, sehingga siswa dapat menemukan ide-ide sendiri dan mengambil maknanya sendiri (Lete, et al., 2016). Guided discovery juga menekankan pola dasar dalam melakukan kegiatan pengamatan, merumuskan masalah, merumuskan hipotesis, mengumpulkan data, mengolah data, menganalisis data, menarik kesimpulan dan mengkomunikasikan. Pola dasar dalam model pembelajaran guided discovery tersebut merupakan bagian dari keterampilan proses sains.

Model pembelajaran guided discovery merupakan model pembelajaran yang mengarahkan siswa pada kegiatan yang dapat mengembangkan keterampilan proses sains dimana siswa dibimbing untuk menemukan dan menyelidiki sendiri tentang suatu konsep sains sehingga pengetahuan dan keterampilan proses sains yang dimiliki siswa bukan hasil mengingat seperangkat konsep yang diberikan melainkan hasil temuan mereka sendiri (Suryasubroto, 2002). Hal ini sesuai dengan yang disampaikan oleh Lete et al. (2016) bahwa model pembelajaran guided discovery dapat mengasah sikap ilmiah, keterampilan proses sains dan meningkatkan hasil belajar kognitif.

Pada pembelajaran dengan menggunakan model pembelajaran guided discovery peran guru hanya sebagai motivator dan fasilitator, tidak sebagai pemberi jawaban akhir atas permasalah yang diberikan. Sedangkan pada pembelajaran konvensional, pada tahap awal guru menyampaikan materi kepada siswa sehingga masih didominasi oleh guru dan siswa hanya menerima informasi dari guru. Selanjutnya guru membagikan LKS kepada siswa dan memfasilitasi siswa untuk dalam melakukan kegiatan praktikum untuk dapat menyelesaikan LKS yang diberikan dan mendiskusikan hasil praktikum yang diperoleh. Setelah menyelesaikan dan mendiskusikan LKS siswa diberikan kesempatan untuk mempresentasikan hasilnya, tetapi rasa tanggungjawab tidak menyebar kesetiap anggota kelompok. Berdasarkan pengamatan peneliti, pada saat diskusi kelompok terlihat banyak anggota kelompok yang hanya menunggu jawaban temannya tanpa ikut berpartisipasi dalam diskusi sehingga menyebabkan peningkatan keterampilan proses sains siswa masih kurang optimal.

Ditinjau dari sudut pandang pemberian LKS (Lembar Kerja Siswa), LKS yang diberikan pada kelas eksperimen yang menggunakan model pembelajaran guided discovery dirancang untuk mengkonstruksi pengetahuan dan keterampilan proses sains siswa. LKS tersebut membantu siswa untuk melaksanakan kegiatan praktikum yang berhubungan dengan materi sistem organisasi kehidupan. LKS model pembelajaran guided discovery berisikan tahapan kinerja ilmiah yang mampu meningkatkan keterampilan proses sains siswa. Siswa menentukan rumusan masalah, menentukan variabel praktikum, 
menafsirkan hasil penelitian dan menentukan hipotesis praktikum dan guru hanya berperan sebagai fasilitator. Berbeda pada LKS model pembelajaran konvensional. Pembelajaran dengan LKS ini tidak mengarahkan siswa untuk dapat meningkatkan keterampilan proses sains. Siswa tidak diarahkan untuk dapat merumuskan masalah, menentukan hipotesis, dan merumuskan variabel penelitian serta menafsirkan hasil penelitian yang diperoleh. Siswa hanya belajar langkah-langkah dalam melaksanakan kegiatan praktikum berdasarkan instruksiinstruksi yang diberikan oleh gurunya.

Keunggulan-keunggulan model pembelajaran guided discovery ini didukung oleh beberapa hasil penelitian, diantaranya yaitu penelitian yang dilakukan oleh Handayani et al. (2017) "Meningkatkan Keterampilan Proses Sains Melalui Model Guided Discovery" dan penelitian yang dilakukan oleh Shalihah (2017) "Penerapan Metode Guided Discovery untuk Meningkatkan Keterampilan Proses Sains Siswa Kelas V Netral D" menunjukkan bahwa penerapan model pembelajaran guided discovery dapat meningkatkan keterampilan proses sains siswa. Berdasarkan pemaparan tersebut, maka terbukti secara empiris dan teoretis bahwa model pembelajaran guided discovery mampu meningkatkan keterampilan proses sains.

\section{SIMPULAN DAN SARAN Simpulan}

Berdasarkan rumusan masalah, tujuan, hasil analisis, dan pembahasan yang telah diuraikan pada bab sebelumnya, dapat disimpulkan bahwa terdapat perbedaan keterampilan proses sains antara siswa yang diberi pelajaran dengan menggunakan model pembelajaran guided discovery dengan siswa yang diberi pelajaran dengan menggunakan model pembelajaran konvensional.

\section{Saran}

Berdasarkan hasil penelitian yang telah dilakukan, peneliti melalui tulisan ini menyampaikan beberapa saran sebagai berikut.
Pertama, pada saat melaksanakan kegiatan pembelajaran, gambar print out yang digunakan untuk objek pengamatan awal memiliki kualitas gambar yang buruk sehingga siswa mengalami kesulitan dalam proses pengamatan. Guru atau peneliti lain yang ingin menggunakan gambar sebagai objek pengamatan awal disarankan untuk menggunakan gambar yang memiliki kualitas yang bagus atau dapat pula dengan menggunakan gambar atau video yang berbantuan LCD dan proyektor.

Kedua, indikator keterampilan proses sains pada aspek bertanya, menafsirkan, merencanakan kegiatan dan menerapkan konsep telah mampu ditingkatkan dengan menggunakan model pembelajaran guided discovery. Hal ini dikarenakan tahapan dalam model pembelajaran guided discovery memberikan kesempatan kepada siswa untuk belajar secara mandiri dan lebih aktif sehingga siswa mampu untuk meningkatkan aspek keterampilan proses sains yang dimilikinya. Berdasarkan hal tersebut, bagi praktisi pendidikan disarankan untuk mempertimbangkan model pembelajaran guided discovery sebagai salah satu alternatif model pembelajaran yang dapat diterapkan di kelas terutama apabila ingin meningkatkan keterampilan proses sains siswa.

Ketiga, guru atau peneliti yang ingin menggunakan model pembelajaran guided discovery atau model pembelajaran lainnya yang menggunakan sistem kelompok diharapkan lebih mengarahkan dan membagi tugas siswa agar siswa tidak terlalu bergantung pada teman satu kelompoknya sehingga siswa juga dapat lebih aktif dalam mengikuti kegiatan pembelajaran.

\section{DAFTAR RUJUKAN}

Ardiansyah, D. $2014 . \quad$ "Analisis Keterampilan Proses Sains Siswa pada Mata Pelajaran Asam Basa Menggunakan Model Pembelajaran Guided Inquiry". Skripsi. Tersedia pada http://repository.uinjkt. ac.id/ dspace / bitstream /123456789 /25455/1/Dede\%40watermack\%20 
ok.pdf (diakses tanggal 8 Desember 2017)

Arikunto, S. 2006. Prosedur Penelitian: Suatu Pendekatan Praktik. Jakarta: Rineka Cipta

Arikunto, S. 2009. Manajemen Penelitian. Jakarta: Rineka Cipta

Duran, M. \& Özdemir, O. 2010. "The Effects of Scientific Process Skills-Based Science Teaching on Students' Attitudes Towards Science". Pdf. US China Education Review. 7 (3), 17-28. Tersedia pada http://www.airitilibrary.com/Publicat ion/alDetailedMesh\%3Fdocid (diakes pada tanggal 20 Mei 2017)

Handayani, B. T., et al. 2017. "Meningkatkan Keterampilan Proses Sains Melalui Model Guided Discovery Learning". Pdf. Jurnal IImiah Pendidikan Fisika. Volume 1 No. 3. Tersedia pada http://fkip. jtam. unlam.ac.id/index.php/jipf/article/do wnload/275/pdf (diakses tanggal 20 Maret 2017)

Juliantara, K. 2009. Pendekatan Pembelajaran Konvensional. Tersedia pada http:// edukasi. kompasiana. com/2009/ 12/20/ pendekatan-pembelajarankonvensional/ (diakses tanggal 7 Desember 2017).

Kuswanto, et al. 2017. "Profil Kemampuan Awal Keterampilan Proses Sains Mahasiswa Baru Pendidikan Fisika Tahun Ajaran 2016/2017 dalam Melakukan Praktikum Fisika Dasar 1 di Universitas Jambi". Artikel IImiah. Tersedia pada http:// repository.unja.ac.id/1773/1/A1C31 3016-ARTIKEL.pdf (diakses tanggal 7 Desember 2017)

Lancour, A. K. 2009. "Science Process Skill". Pdf. Process Skills For Life Sicence (04)Training Guide.
Tersedia pada http://scioly .org/ wiki/ images/d/ d6/ Pslsl_training_ hammond04.pdf (diakses pada tanggal 20 Maret 2017)

Lete, M, et al. 2016. "Peningkatan Keterampilan Proses Sains Siswa Melalui Pembelajaran Discovery Topik Tekanan Hidrostatis". Pdf. Pros. Semnas Pend. IPA Pascasarjana UM. Vol. 1, 2016. Tersedia pada http://pasca.um.ac.id/wp-content /uploads/2017/02/Maksem-Lete1020-1032.pdf (diakses pada tanggal 16 April 2017)

Mardana, I. B. (2006). "Implementasi Modul Eksperimen Sains Berbasis Kompetensi dengan Model Experiential Learning dalam Upaya Meningkatkan Kualitas Pelaksanaan KBK dalam Pembelajaran Sains di SMP Negeri Sukasada". Pdf. Jurnal Pendidikan dan Pengajaran IKIP Singaraja. 39 (4): 782 - 797. Tersedia pada https://nanopdf.com/download File/ pembelajaran -materi- ajarsuplemen-berbasis-kbk-denganmodel_pdf?preview=1 (diakses tanggal 29 Juli 2018)

Moedjiono, \& M. Dimyati. 1992. Strategi Belajar Mengajar. Jakarta: Depdikbud

Ozturk, N., Tezel, O. \& Acat, M. B. 2010. "Science Process Skills of Primary School Seventh Grade Student in Science Technology Lesson". Pdf. Journal of Turkish Science Education. 7(3), 15-28. Tersedia pada

https://www.researchgate.net/publi cation/228465007_Science_Proce ss_Skills_Levels_of_Primary_Scho ol_Seventh_Grade_Students_in_S cience_and_Technology_Lesson (diakses pada tanggal 20 Mei 2017) 
Shalihah, T. R. 2017. "Penerapan Metode Guided Discovery untuk Meningkatkan Keterampilan Proses Sains Siswa Kelas V Netral D. Pdf. Jurnal Pendidikan Guru Sekolah Dasar Edisi 5 Tahun ke-6 2017. Tersedia pada http://journal. student.uny.ac.id /ojs/index.php/ pgsd/article/download/7010/6730 (diakses pada tanggal 16 April 2017)

Suastra, I. W. 2009. Pembelajaran Sains Terkini. Singaraja: Universitas Pendidikan Ganesha.

Subagyo, et al. 2009. "Pembelajaran dengan Pendekatan Keterampilan Proses Sains untuk Meningkatkan Penguasaan Konsep Suhu dan Pemuaian". Pdf. Jurnal Pendidikan Fisika Indonesia. 5, 42-46. Tersedia pada https:// journal. unnes.ac.id/nju/index.php/JPFI/arti cle/download/999/917 (diakses pada tanggal 15 Mei 2018)

Sudargo, F \& Soesy A. S. 2010. "Kemampuan Pedagogik Calon Guru Biologi dalam Meningkatkan Kemampuan Berpikir Kritis dan Keterampilan Proses Siswa melalui Pembelajaran Berbasis Praktikum". Jurnal Pengajaran MIPA. 15 (1), 412. Tersedia pada http://journal. fpmipa.upi.edu/index.php/jpmipa/ar ticle/download/287/198 (diakses tanggal 7 Desember 2017)

Sugiyono, 2015. Metode Penelitian Pendidikan. Bandung: Alfabeta

Sukardi, I. 2015. "Pengaruh Metode Pembelajaran Discovery Learning Terhadap Hasil Belajar Siswa pada Mata Pelajaran Biologi Kelas VII di MTs Patra Mandiri Plaju Palembang". Bioilmi Vol. 1 No. 1 Edisi Agustus 2015. Tersedia pada http://jurnal.radenfatah.ac.id/ index. $\mathrm{php/} \mathrm{bioilmi/article/} \mathrm{view} \mathrm{File/} \mathrm{1127/}$ 945 (diakses tanggal 7 Desember 2017)
Suryasubroto, B. 2002. Proses Belajar Mengajar di Sekolah. Jakarta: PT Rineka Cipta.

Warnata, I. M. 2009. Pengaruh Model Pembelajaran Inkuiri terhadap Keterampilan Proses Sains Ditinjau dari Gaya Berpikir Peserta Didik SMP Negeri 3 Kediri Tabanan. Tesis (tidak diterbitkan). Universitas Pendidikan Ganesha. 